\title{
Involvement of Neurokinin Receptors in the Control of Pulsatile Luteinizing Hormone Secretion in Rats
}

\author{
Ken-ichi NORITAKE ${ }^{1)}$, Toshiki MATSUOKA ${ }^{1)}$, Tetsuya OHSAWA ${ }^{1)}$, Kazuhiro SHIMOMURA ${ }^{1)}$, \\ Atsushi SANBUISSHO'), Yoshihisa UENOYAMA ${ }^{2)}$, Kei-ichiro MAEDA ${ }^{2)}$ and \\ Hiroko TSUKAMURA ${ }^{2)}$
}

\begin{abstract}
${ }^{1)}$ Medicinal Safety Research Laboratories, Daiichi Sankyo Co., Ltd., Shizuoka 437-0065 and ${ }^{2)}$ Laboratory of Reproductive Science, Graduate School of Bioagricultural Sciences, Nagoya University, Nagoya 464-8601, Japan
\end{abstract}

\begin{abstract}
It has recently been shown that neurokinin B, a tachykinin, is associated with GnRH pulse generation in sheep and goats. The aim of the present study was to clarify the role of tachykinin receptors in the control of LH secretion in rats. To this end, we evaluated the effect of CS-003, an antagonist for all three neurokinin receptors (NK1, NK2 and NK3 receptors), on pulsatile LH secretion in both sexes of rats with different routes of administration. Both oral and third ventricular administration of CS-003 suppressed LH secretion in both sexes of gonadectomized animals. Furthermore, intact male rats with oral administration of CS-003 showed decreased serum testosterone levels, which might be due to suppressed LH secretion. None of the three subtype-specific neurokinin receptor antagonists showed a significant effect on LH secretion in ovariectomized rats when each antagonist was singly administered. The present results suggest that neurokinins play a role in the control of pulsatile GnRH/LH secretion via multiple neurokinin receptors in both male and female rats.
\end{abstract}

Key words: Luteinizing hormone, Neurokinin, Rat, Receptor

(J. Reprod. Dev. 57: 409-415, 2011)

$\mathbf{P}$ ulsatile gonadotropin-releasing hormone $(\mathrm{GnRH}) /$ luteinizing hormone $(\mathrm{LH})$ release is indispensable for regulation of gonadal functions, such as folliculogenesis, spermatogenesis and steroidogenesis, in rodents [1], ruminants [2, 3] and primates [4]. The mechanism generating GnRH/LH pulses, called the GnRH pulse generator, has been suggested to be localized in the hypothalamus [5]. Recent studies have revealed that kisspeptin neurons located in the hypothalamus play a central role in regulating $\mathrm{GnRH}$ release [6,7]. Kisspeptin neurons have two populations in the hypothalamus [8]: One is located in the hypothalamic arcuate nucleus (ARC), and the other is located in the anteroventral periventricular nucleus (AVPV). Of these two populations, the AVPV kisspeptin neurons have been reported to be involved in the regulation of $\mathrm{GnRH} / \mathrm{LH}$ surge $[9,10]$. On the other hand, the role of ARC kisspeptin neurons is still unclear, but several lines of evidence suggest that the population is associated with GnRH pulse generation [11].

Recent studies have shown an interesting and essential aspect of the ARC kisspeptin neurons. Most kisspeptin neurons have neurokinin B (NKB) and dynorphin (Dyn) in sheep [12], goats [13] and rodents [14], and thus the neurons have been called KNDy neurons [15]. Colocalization of those three neuropeptides in the ARC neurons might be associated with GnRH pulse generation. It has recently been reported that mutations of genes encoding $\mathrm{NKB}$ and its receptor are associated with gonadotropin deficiency in humans

Received: January 5, 2011

Accepted: January 17, 2011

Published online in J-STAGE: February 25, 2011

(C)2011 by the Society for Reproduction and Development

Correspondence: H Tsukamura (e-mail: htsukamura@nagoya-u.jp)
[16], and central administration of a selective NKB receptor agonist stimulates LH secretion in sheep [17] and monkeys [18]. These reports indicate the significance of NKB/NK3 signaling in $\mathrm{GnRH} /$ gonadotropin release in these animal species. In addition to neurokinin $\mathrm{B}$, nor-BNI, a $\kappa$-opioid receptor antagonist (KOR), reversed the inhibitory effect of progesterone on pulsatile $\mathrm{LH}$ secretion $[19,20]$. In goats, a previous study suggests that NKB/ NK3 signaling plays a role in facilitating GnRH pulse generator activity by activation of the ARC kisspeptin neurons, whereas Dyn/ KOR signaling is involved in inhibiting the pulse generator activity. Thus, GnRH pulse generation would be closely associated with the activity of KNDy neurons.

NKB belongs to neurokinin family, which has the common Cterminal sequence of Phe-X-Gly-Leu-Met- $\mathrm{NH}_{2}$ [21]. The family also involves substance P (SP), neurokinin A (NKA), neuropeptide $\mathrm{K}(\mathrm{NPK})$ and neuropeptide $\gamma(\mathrm{NP} \gamma)$ in mammals with a wide distribution in the nervous system [22]. Three types of G-protein coupled neurokinin receptors are also found in the central and peripheral nervous system [23-25]. SP, NKA and NKB bind preferentially to the NK1, NK2 and NK3 receptor, respectively [26], but each of these three neuropeptides is capable of eliciting responses from all three neurokinin receptors [27]. Our recent study showed that oral administration of an antagonist for all three neurokinin receptors (NK1, NK2 and NK3 receptors) has testicular toxicity through inhibition of gonadotropin secretion in dogs [28], suggesting that the reproductive toxicity of the antagonist might be associated with the mechanism of GnRH pulse generation.

Tac1 (gene encoding SP, NKA, NPK and NP $\gamma$ ) and Tac2 (gene encoding NKB) mRNA-expressing neurons are located in several hypothalamic nuclei such as the medial preoptic area and ARC in 
rats $[29,30]$. SP or NPK neurons project their fibers to hypothalamic areas such as the medial preoptic area [31, 32], paraventricular nucleus [33] and ARC in rats [34]. SP-immunoreactive fibers were found in GnRH neurons in humans and rats [35, 36]. Earlier studies have demonstrated that Tac1 products such as SP and NPK stimulated [37, 38], suppressed [39, 40] or did not affect $\mathrm{LH}$ secretion in rats. On the other hand, NKB neurons project their fibers to the external zone in the median eminence in rodents and ruminants [12, 13, 41-43]. Additionally, Krajewski et al. [44] showed that a dense interweaving and close apposition of GnRH and NKB-immunoreactive fiber was observed within the rat median eminence, where GnRH axons expressed NK3 receptor immunoreactivity. Indeed, central injection of senktide, an NK3 receptor agonist, inhibited $\mathrm{LH}$ secretion in rats and mice [14, 45], although NK3 receptor knockout mice are fertile [46]. The overlapping binding activities of neurokinins on their three types of receptor makes it difficult to understand the role of neurokinins in reproductive functions [27]. In addition, the role of NKB in regulating GnRH release has been well documented in monkeys [18], sheep [17] and goats [13], but not fully elucidated in rats.

The aim of the present study was to clarify the roles of neurokinin system in reproductive functions in the rat. To this end, we first evaluated the effect of peripheral and central administration of a triple neurokinin receptor antagonist on pulsatile LH secretion in both male and female rats and then the effect of specific antagonists for each type of neurokinin receptor.

\section{Materials and Methods}

\section{Animals}

Male and female Wistar-Imamichi strain adult rats weighing 250-300 g were kept under the following conditions: $12 \mathrm{~h}$ light: 12 $\mathrm{h}$ darkness (lights on at $0700 \mathrm{~h}$ ), $22 \pm 2 \mathrm{C}$ and free access to food (Certified Rodent Diet 5002, PMI Nutrition International, St. Louis, MO, USA) and water. Vaginal smears of female rats were checked daily to confirm normal estrous cyclicity. Gonadectomized male and female rats were used to determine the effects of neurokinin receptor antagonists on $\mathrm{LH}$ release. Intact males were used to test the effect of a neurokinin receptor antagonist on serum testosterone levels. All surgeries were conducted under ketamine/ xylazine anesthesia and aseptic conditions. This study was conducted according to the in-house guidelines provided by the Institutional Animal Care and Use Committee of Daiichi Sankyo.

\section{Drugs}

CS-003, [1-\{2-[(2R)-(3,4-dichlorophenyl)-4-(3,4,5-trimethoxybenzoyl)morpholin-2-yl]ethyl $\}$ spiro [benzo[c]thiophene-1(3H),4'piperidine]-(2S)-oxide hydrochloride], has been confirmed to be an orally active triple neurokinin receptor antagonist [47, 48]. Briefly, CS-003 inhibited substance P-induced tracheal vascular permeability, NKA-induced bronchoconstriction and NKB-induced bronchoconstriction in guinea pigs. The antagonists for each type of neurokinin receptor were FK888 (NK1 receptor antagonist, $\mathrm{N}^{2}$ [(4R)-4-hydroxy-1-(1-methyl-1H-indol-3-yl) carbonyl-L-propyl]$\mathrm{N}$-methyl-N-phenylmethyl-3-(2-naphthyl)-L-alaninamide) [49], SR48968 (NK2 receptor antagonist, (S)-N-methyl-N[4-(4-acety- lamino-4-phenyl piperidino)-2-(3,4-dichlorophenyl)butyl]benzamide)[50] and SB223412 (NK3 receptor antagonist, [(S)-(-)N-( $\alpha$-ethylbenzyl)-3-hydroxy-2-phenylquinoline-4-carboxamide]) [51]. All drugs were synthesized by Sankyo (Tokyo, Japan).

\section{Brain surgery}

The animals were stereotaxically implanted with a stainless steel guide cannula (23 gauge; Plastics One, Roanoke, VA, USA) for drug injection into the third cerebroventricle $(3 \mathrm{~V})$ with the tip end $0.8 \mathrm{~mm}$ posterior and $7.5 \mathrm{~mm}$ ventral to the bregma at midline according to a rat brain atlas [52]. The animals were allowed a oneweek recovery period prior to blood sampling.

\section{Drug administration and blood sampling}

CS-003 (1000 mg/kg BW), a triple neurokinin receptor antagonist, suspended in $0.5 \%$ tragacanth suspension at $20 \%$ concentration was orally administered to male or female rats using a glass syringe and a metal stomach tube (Natsume Seisakusho, Tokyo, Japan) at a dose of $5 \mathrm{ml} / \mathrm{kg}$ BW. This dose was chosen because our previous study revealed that oral CS-003 administration did not have a testicular toxicity at $100 \mathrm{mg} / \mathrm{kg} \mathrm{BW}$ in rats (unpublished observation). Control animals were administered with an equivalent volume of $0.5 \%$ tragacanth suspension in a similar manner. Blood samples $(100 \mu \mathrm{l})$ were collected from freemoving conscious rats at 6-min intervals for $3 \mathrm{~h}$ through an indwelling atrial cannula (i.d., $0.5 \mathrm{~mm}$; o.d., $1.0 \mathrm{~mm}$; Shin-Etsu Polymer, Tokyo, Japan) that was inserted through the right jugular vein on the day before blood sampling. Blood sampling started at 3 $\mathrm{h}$ after drug administration because drug concentrations in the blood peak around $4 \mathrm{~h}$ after oral administration (unpublished observation). An equivalent volume of rat red blood cells taken from donor rats and diluted with heparinized saline was replaced through the atrial cannula after each blood collection.

CS-003, FK888, SR48968 and SB223412 were injected into the $3 \mathrm{~V}$ at doses of 0.1 or $1 \mu \mathrm{mol}$. The higher dose for these drugs was approximately two hundredth of the dose administered orally. Drugs were dissolved in dimethyl sulfoxide (DMSO) and injected into the $3 \mathrm{~V}$ of conscious ovariectomized rats at a rate of $1 \mu \mathrm{l} / \mathrm{min}$ for 2 min using a microsyringe pump (Eicom, Kyoto, Japan) through an internal cannula (26 gauge; Plastics One, Roanoke, VA, USA) inserted into the guide cannula. Control animals were injected with an equivalent volume of DMSO in a similar manner. Blood samples $(100 \mu \mathrm{l})$ were collected every $6 \mathrm{~min}$ for $3 \mathrm{~h}$ immediately after the $3 \mathrm{~V}$ injection as the oral administration experiment. At the end of the experiment, the animals were anesthetized and infused with $2 \%$ brilliant blue dye solution at the same flow rate as drug administration to ascertain if drugs were infused into the $3 \mathrm{~V}$. The brain was removed, and cannula placement was verified by visual inspection. All animals were confirmed to have correct cannula placement.

To determine the effects of CS-003 (1000 mg/kg BW, po) on serum testosterone levels, a 20\% suspension of CS-003 was administered to intact male rats as described above. Blood samples (200 $\mu \mathrm{l})$ for testosterone assay were collected from free-moving conscious rats at 30 -min intervals for $8 \mathrm{~h}$ through an indwelling atrial cannula as described above. 
Assays

Plasma LH concentrations were determined in 50- $\mu$ l plasma samples by a double-antibody radioimmunoassay (RIA) using a rat LH RIA kit provided by the National Hormone and Peptide Program (Torrance, CA, USA). Values were expressed in terms of NIDDK rat LH PR-3. The least detectable level was $0.156 \mathrm{ng} / \mathrm{ml}$, and the intra- and interassay coefficients of variation were $4.9 \%$ at $1.3 \mathrm{ng} / \mathrm{ml}$ and $2.7 \%$ at $2.3 \mathrm{ng} / \mathrm{ml}$, respectively. Serum testosterone concentrations were determined in $25-\mu l$ serum samples by a fluoroimmunoassay with the DELFIA testosterone reagents (R050-201, PerkinElmer Japan, Tokyo, Japan). The least detectable level was $0.09 \mathrm{ng} / \mathrm{ml}$, and the intra- and interassay coefficients of variation were 5.7 and $10.3 \%$, respectively.

\section{Data analysis}

LH pulses were identified by the PULSAR computer program [53] as previously described [54]. Mean and baseline LH concentrations and the frequency and amplitude of LH pulses during the 3$\mathrm{h}$ sampling period were calculated for each individual and then for each group. Statistical differences in LH pulse parameters and serum testosterone levels between oral CS-003- and vehicle-treated rats were determined by the Student's $t$-test. The significance of differences in LH pulse parameters between groups with icv injection of drugs were determined by one-way ANOVA followed by the Dunnett's test.

\section{Results}

\section{Effects of oral administration of CS-003 on LH and testosterone} secretion

Pulsatile LH secretion was suppressed by oral CS-003 administration in both gonadectomized females and males (Figs. 1A and 1B). The mean plasma LH levels and frequency and baseline of LH pulses were significantly decreased in the CS-003-treated ovariectomized females compared with the vehicle-treated group $(\mathrm{P}<0.05$, Student's $t$-test). The mean plasma LH levels and baseline of LH pulses were significantly lower in the CS-003-treated castrated males than in the vehicle-treated controls $(\mathrm{P}<0.05$, Student's $t$-test).

In intact males, the serum testosterone level was suppressed immediately after oral CS-003 administration, and the suppression lasted until $8 \mathrm{~h}$ after administration (Fig. 1C). The level was significantly lower in the CS-003-treated animals than in the vehicletreated control group from $2.5 \mathrm{~h}$ to $8 \mathrm{~h}$ after CS-003 administration $(\mathrm{P}<0.05$, Student's $t$-test $)$.

\section{Effects of $3 V$ injection of CS-003 on LH secretion}

Pulsatile LH secretion was suppressed by $3 \mathrm{~V}$ CS-003 injection in both the gonadectomized females and males in a dose-dependent manner (Figs. 2A and 2B). LH pulse frequency was significantly lower in the ovariectomized female rats treated with $1 \mu \mathrm{mol} \mathrm{CS}-$ 003 compared with the vehicle-treated controls $(\mathrm{P}<0.05$, Dunnett's test). The mean plasma LH levels and frequency of $\mathrm{LH}$ pulses were significantly decreased by $1 \mu$ mol CS- 003 in the castrated males compared with the vehicle-treated males $(\mathrm{P}<0.05$, Dunnett's test).
Effects of $3 V$ injection of subtype-specific neurokinin receptor antagonists on LH secretion

Profiles of LH secretion in representative ovariectomized rats that received $3 \mathrm{~V}$ administration of subtype-specific neurokinin receptor antagonists, FK888, SR48968 and SB223412, are shown in Fig. 3A. There was no significant effect of injection of any antagonist on pulsatile LH secretion and LH pulse parameters (Figs. 3A and 3B).

\section{Discussion}

The present study showed that oral administration of a triple neurokinin receptor antagonist (CS-003) suppressed testosterone secretion in intact male rats. The decreased testosterone levels could be due to the CS-003-induced suppression of LH secretion because oral administration of CS-003 significantly suppressed plasma LH levels in castrated male rats. Thus, one of the possible action sites for CS-003-induced testicular dysfunction is the hypothalamo-pituitary axis. Indeed, central administration of CS-003 in the current study suppressed pulsatile LH secretion in male rats. Taken together, these results suggest that one of the action sites of CS-003 to suppress GnRH secretion and then LH and testosterone release would be the hypothalamus. The present study showed that simultaneous blockade of the 3 types of neurokinin receptor by central CS-003 administration caused a dysfunction of the pulsatile GnRH release system, resulting in decreased LH levels in male and female rats. Thus, neurokinins might play a role in generating $\mathrm{GnRH} / \mathrm{LH}$ pulses in both sexes.

The present study showed that specific antagonists of NK1, NK2 or NK3 receptor failed to suppress plasma LH levels in ovariectomized rats when each antagonist was singly administered. This result suggests that multiple neurokinin receptors are involved in the mechanism generating pulsatile $\mathrm{GnRH} / \mathrm{LH}$ secretion in rats. Affinity of CS-003 for neurokinin receptors has been analyzed by in vivo and in vitro studies and is relatively higher for the NK3 and NK2 receptors compared with the NK1 receptor [48, 55]. Recently, several investigators have actually reported a close association of NKB-NK3 receptor signaling with GnRH secretion in several mammalian species including humans. Topaloglu et al. [16] showed that mutations of either TAC3 or TAC3R, which encode NKB or NK3 receptor, respectively, are associated with gonadotropin deficiency and pubertal failure in humans. This implies the significance of NKB-NK3 receptor signaling in GnRH pulse generation in humans. Goodman et al. found that both NKB and Dyn are coexpressed in the ARC kisspeptin neurons in sheep [12] and are therefore referred to as KNDy neurons [15], suggesting that such phenotype neurons have a critical role in regulating GnRH secretion in sheep. Navarro et al. found KNDy neurons in the ARC of mice [14] and hypothesized that the KNDy neurons are an intrinsic source of the GnRH pulse generator in mice. Indeed, GnRH pulse generator activity, which is recorded as rhythmic volleys of multiple unit activity accompanied by LH pulses, has been detected in the ARC of goats where kisspeptin neuronal cell bodies were densely found [56]. Furthermore, NKB stimulates GnRH pulse generator activity in the goats [13]. Intravenous injection of an NK3 receptor antagonist, SB222200, blocked senktide-induced 
A

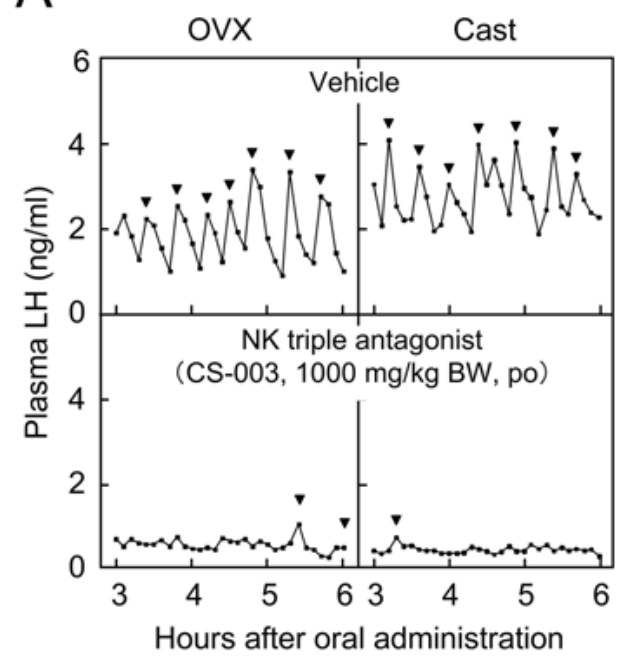

C

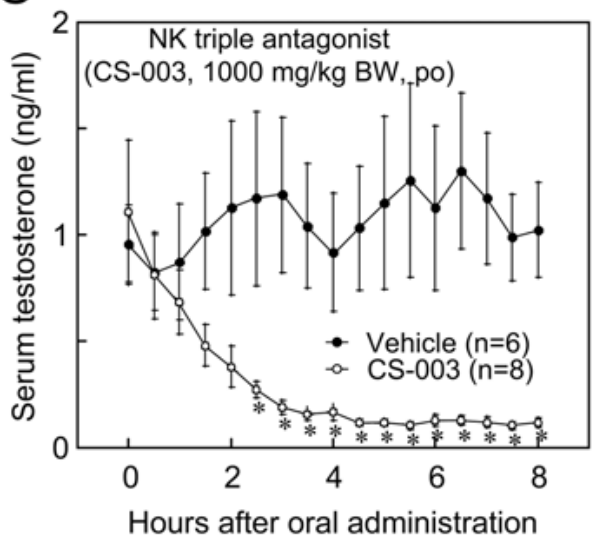

$B$

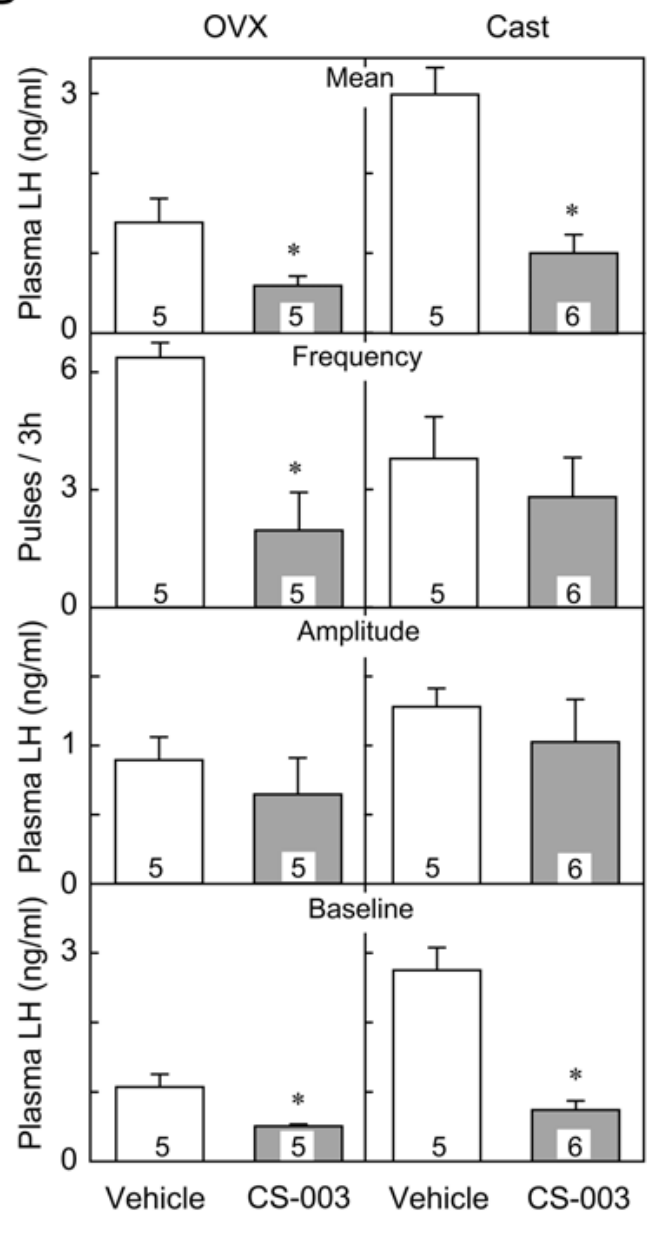

Fig. 1. Effects of oral CS-003 administration on LH and testosterone secretion. A: Plasma LH profiles in representative animals of the ovariectomized (OVX) and castrated (Cast) groups. B: Mean plasma LH concentrations and frequency, amplitude and baseline of LH pulses in OVX and Cast rats. C: Mean serum testosterone concentrations in intact male rats. Arrowheads indicate the peaks of LH pulses identified with the PULSAR computer program. Values are means \pm SEM. The numbers in each column represent the numbers of animals used. $* \mathrm{P}<0.05$ vs. the vehicletreated controls (Student's $t$-test).

LH release in monkeys [18], suggesting that NK3 mediates the stimulatory effect of NKB on LH release. The current result that an NK3R antagonist failed to suppress LH secretion is inconsistent with these previous findings suggesting that NKB-NK3 receptor signaling has a key role in $\mathrm{GnRH}$ pulse generation. Indeed, there is still inconsistency in the role of NKB-NK3 signaling in rodents. Sandoval-Guzman and Rance [45] showed that icv injection of NK3 receptor agonist reduced LH secretion in rats. On the other hand, there are several reports indicating that NKB-NK3 signaling is not involved in GnRH secretion; specifically, Tac3r knockout mice were fertile [46] and peripheral or central administration of NKB had no apparent effect on serum LH levels in mice [57]. In this context, the mechanism generating pulsatile GnRH/LH secretion has not yet been fully elucidated in rodents and may involve species differences.

Besides the hypothalamus, another possible action site for CS- 003-induced testicular dysfunction is the anterior pituitary because Tac1 gene products also contribute to the regulation of LH secretion at the levels of the pituitary. SP-NK1 receptor binding was found in gonadotrophs in cultured anterior pituitary [58]. SP stimulates LH secretion from cultured anterior pituitary cells of female rats [59]. Further, Karla et al. [38] showed that three ligands for NK2 receptor, NKA, NPK and NP $\gamma$, stimulated $\mathrm{LH}$ secretion from the hemipituitaries in vitro. Thus, oral administration of CS-003 might inhibit SP/NK1 and/or NKA/NK2 signaling in the pituitary, resulting in decreased $\mathrm{LH}$ levels and then a decrease in testosterone secretion in male rats.

In conclusion, the present study suggests that neurokinins play a potent role in pulsatile $\mathrm{GnRH} / \mathrm{LH}$ secretion via multiple neurokinin receptors in both male and female rats. Further studies are required to clarify the role of each neurokinin receptor in the regulation of reproductive function in rats. 
A

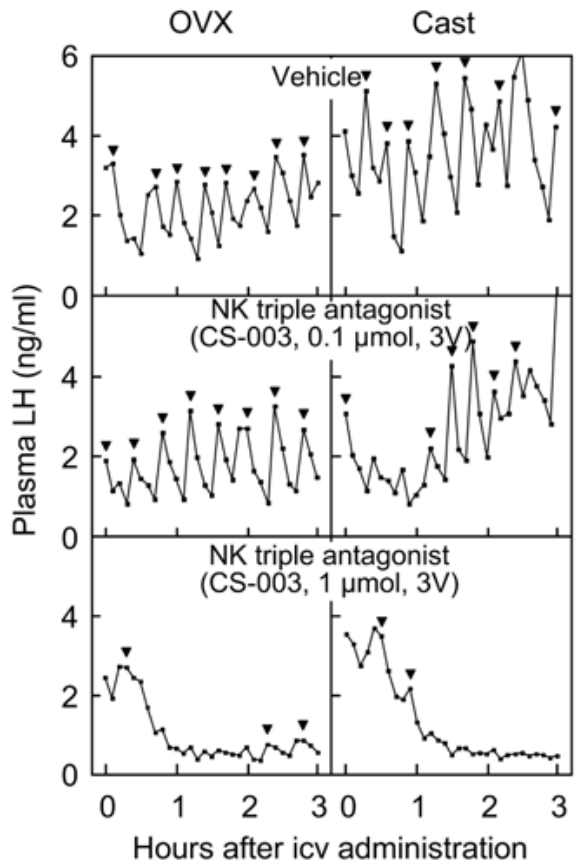

B

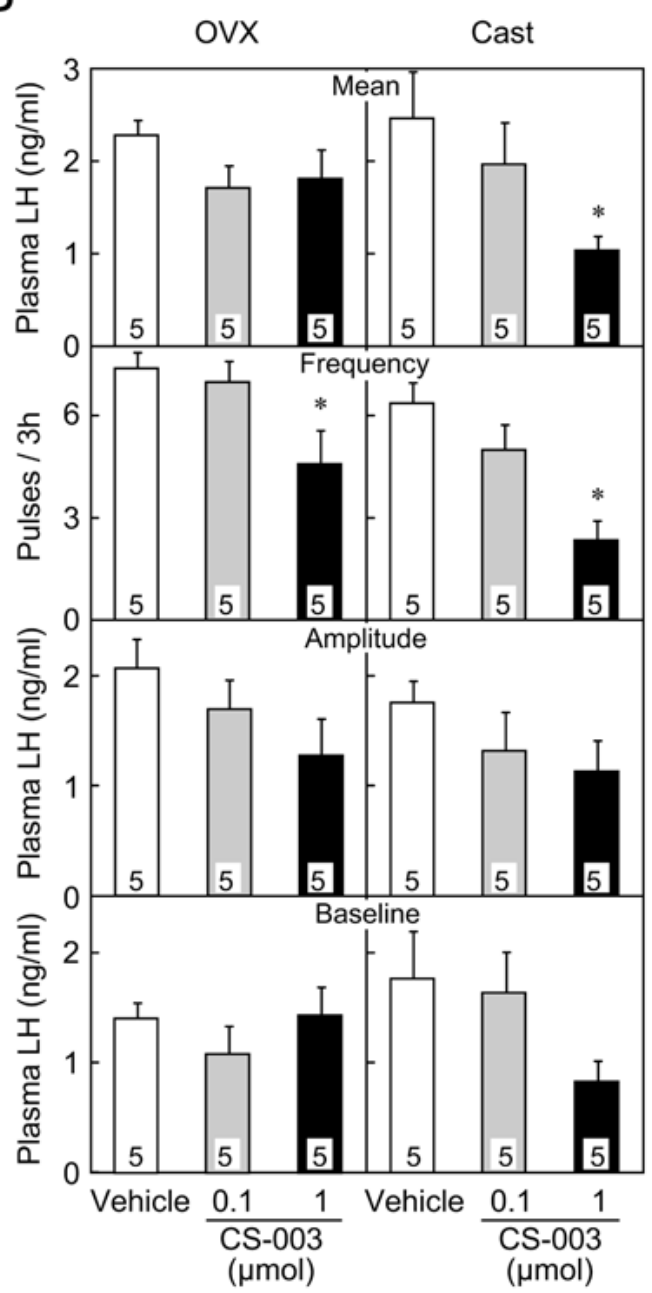

Fig. 2. Effects of third cerebroventricular injection of CS-003 on LH secretion in OVX and Cast rats. A: Plasma LH profiles in representative animals. B: Mean plasma LH concentrations and frequency, amplitude and baseline of LH pulses. Arrowheads indicate the peaks of LH pulses identified with the PULSAR computer program. Values are means \pm SEM. The numbers in each column represent the numbers of animals used. $* \mathrm{P}<0.05$ $v s$. the vehicle-treated group (Dunnett's test).

\section{Acknowledgments}

We are grateful to the National Hormone and Peptide Program for the LH assay kit and to Drs GR Merriam and KW Wachter for the PULSAR computer program. The RIA and LH pulse analyses were performed at the Nagoya University Radioisotope Center and Information Technology Center, respectively.

\section{References}

1. Gay VL, Sheth NA. Evidence for a periodic release of LH in castrated male and female rats. Endocrinology 1972; 90: 158-162.

2. Butler WR, Malven PV, Willett LB, Bolt DJ. Patterns of pituitary release and cranial output of LH and prolactin in ovariectomized ewes. Endocrinology 1972; 91: 793-801.

3. Rahe CH, Owens RE, Fleeger JL, Newton HJ, Harms PG. Pattern of plasma luteinizing hormone in the cyclic cow: dependence upon the period of the cycle. Endocrinology 1980; 107: 498-503.
4. Dierschke DJ, Bhattacharya AN, Atkinson LE, Knobil E. Circhoral oscillations of plasma LH levels in the ovariectomized rhesus monkey. Endocrinology 1970; 87: 850853.

5. Wilson RC, Kesner JS, Kaufman JM, Uemura T, Akema T, Knobil E. Central electrophysiologic correlates of pulsatile luteinizing hormone secretion in the rhesus monkey. Neuroendocrinology 1984; 39: 256-260.

6. Ohkura S, Uenoyama Y, Yamada S, Homma T, Takase K, Inoue N, Maeda K, Tsukamura $\mathrm{H}$. Physiological role of metastin/kisspeptin in regulating gonadotropin-releasing hormone (GnRH) secretion in female rats. Peptides 2009; 30: 49-56.

7. Oakley AE, Clifton DK, Steiner RA. Kisspeptin signaling in the brain. Endocr Rer 2009; 30: 713-743

8. Smith JT, Cunningham MJ, Rissman EF, Clifton DK, Steiner RA. Regulation of Kiss1 gene expression in the brain of the female mouse. Endocrinology 2005; 146: 3686 3692.

9. Adachi S, Yamada S, Takatsu $Y$, Matsui $H$, Kinoshita $M$, Takase $K$, Sugiura $H_{\text {, }}$ Ohtaki T, Matsumoto H, Uenoyama $Y$, Tsukamura H, Inoue K, Maeda K. Involvement of anteroventral periventricular metastin/kisspeptin neurons in estrogen positive feedback action on luteinizing hormone release in female rats. J Reprod Dev 2007; 53: 367-378.

10. Kinoshita M, Tsukamura H, Adachi S, Matsui H, Uenoyama Y, Iwata K, Yamada S, 


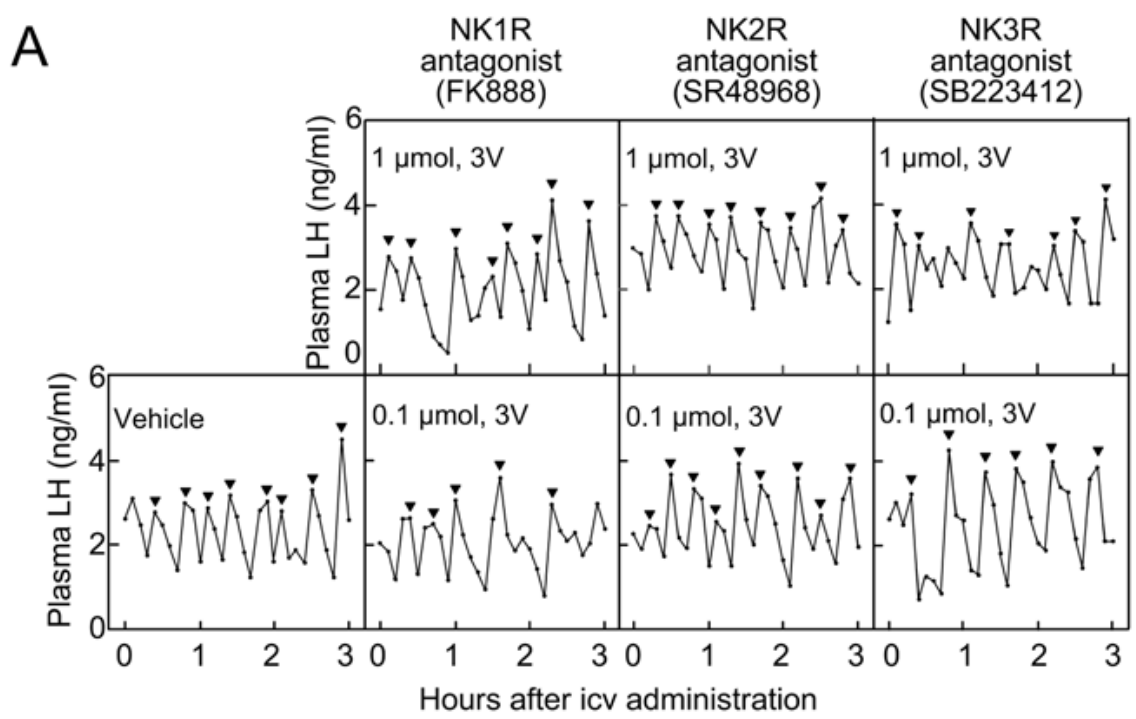

B
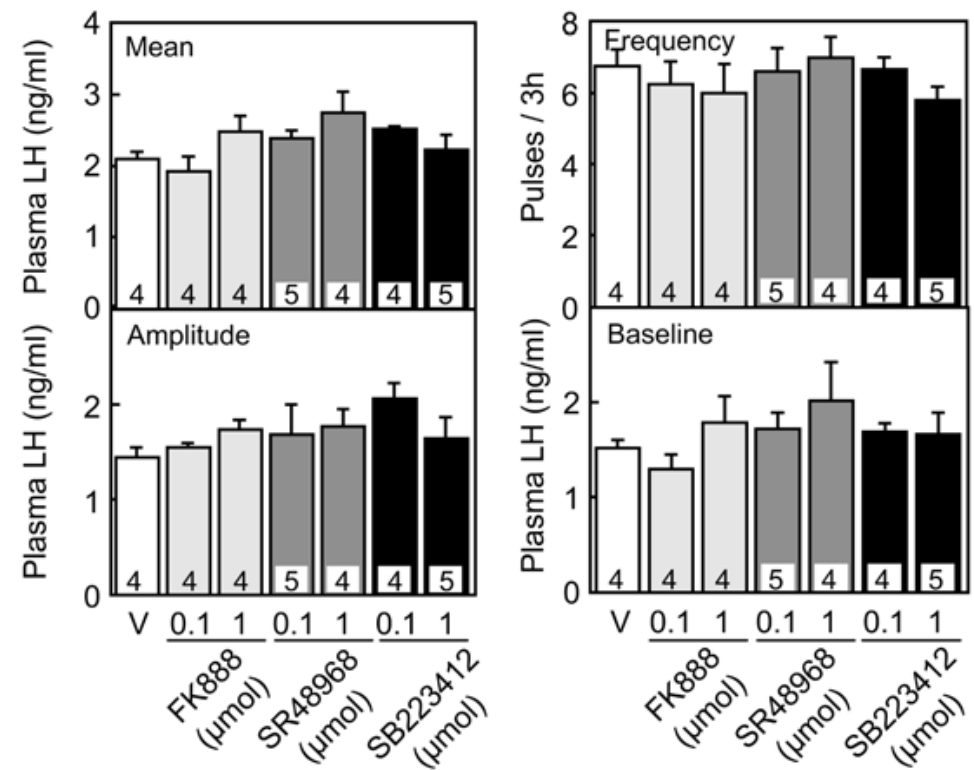

Fig. 3. Effects of third cerebroventricular injection of subtype-specific neurokinin receptor antagonists on LH secretion in OVX rats. A: Plasma LH profiles in representative animals. B: Mean plasma LH concentrations and frequency, amplitude and baseline of LH pulses. Arrowheads indicate the peaks of LH pulses identified with the PULSAR computer program. Values are means \pm SEM. The numbers in each column represent the numbers of animals used. NK1R, neurokinin 1 receptor; NK2R, neurokinin 2 receptor; NK3R, neurokinin 3 receptor.

Inoue K, Ohtaki T, Matsumoto H, Maeda K. Involvement of central metastin in the regulation of preovulatory luteinizing hormone surge and estrous cyclicity in female rats. Endocrinology 2005; 146: 4431-4436.

11. Maeda KI, Ohkura S, Uenoyama Y, Wakabayashi Y, Oka Y, Tsukamura H, Okamura H. Neurobiological mechanisms underlying GnRH pulse generation by the hypothalamus. Brain Res 2010; 1364: 103-115.

12. Goodman R, Lehman M, Smith J, Coolen L, de Oliveira C, Jafarzadehshirazi M, Pereira A, Iqbal J, Caraty A, Ciofi P, Clarke I. Kisspeptin neurons in the arcuate nucleus of the ewe express both dynorphin A and neurokinin B. Endocrinology 2007; 148: 5752-5760.

13. Wakabayashi Y, Nakada T, Murata K, Ohkura S, Mogi K, Navarro V, Clifton D, Mori Y, Tsukamura H, Maeda K, Steiner R, Okamura H. Neurokinin B and dynorphin $\mathrm{A}$ in kisspeptin neurons of the arcuate nucleus participate in generation of periodic oscillation of neural activity driving pulsatile gonadotropin-releasing hormone secretion in the goat. J Neurosci 2010; 30: 3124-3132.

14. Navarro V, Gottsch M, Chavkin C, Okamura H, Clifton D, Steiner R. Regulation of gonadotropin-releasing hormone secretion by kisspeptin/dynorphin/neurokinin B neurons in the arcuate nucleus of the mouse. J Neurosci 2009; 29: 11859-11866.

15. Lehman MN, Coolen LM, Goodman RL. Minireview: kisspeptin/neurokinin B/ dynorphin (KNDy) cells of the arcuate nucleus: a central node in the control of gonadotropin-releasing hormone secretion. Endocrinology 2010; 151: 3479-3489.

16. Topaloglu A, Reimann F, Guclu M, Yalin A, Kotan L, Porter K, Serin A, Mungan N, Cook J, Ozbek M, Imamoglu S, Akalin N, Yuskel B, O'Rahilly S, Semple R. TAC3 and TACR3 mutations in familial hypogonadotropic hypogonadism reveal a key role for Neurokinin B in the central control of reproduction. Nat Genet 2009; 41: 354-358.

17. Billings HJ, Connors JM, Altman SN, Hileman SM, Holaskova I, Lehman MN, McManus CJ, Nestor CC, Jacobs BH, Goodman RL. Neurokinin B acts via the neurokinin-3 receptor in the retrochiasmatic area to stimulate luteinizing hormone secretion 
in sheep. Endocrinology 2010; 151: 3836-3846.

18. Ramaswamy S, Seminara SB, Ali B, Ciofi P, Amin NA, Plant TM. Neurokinin B stimulates GnRH release in the male monkey (Macaca mulatta) and is colocalized with kisspeptin in the arcuate nucleus. Endocrinology 2010; 151: 4494-4503.

19. Gallo RV. Kappa-opioid receptor involvement in the regulation of pulsatile luteinizing hormone release during early pregnancy in the rat. J Neuroendocrinol 1990; 2: 685691.

20. Goodman RL, Coolen LM, Anderson GM, Hardy SL, Valent M, Connors JM, Fitzgerald ME, Lehman MN. Evidence that dynorphin plays a major role in mediating progesterone negative feedback on gonadotropin-releasing hormone neurons in sheep. Endocrinology 2004; 145: 2959-2967.

21. Maggio J. Tachykinins. Annu Rev Neurosci 1988; 11: 13-28.

22. Otsuka M, Yoshioka K. Neurotransmitter functions of mammalian tachykinins. Physiol Rev 1993; 73: 229-308.

23. Maggi C. The mammalian tachykinin receptors. Gen Pharmacol 1995; 26: 911-944.

24. Patacchini R, Maggi C. Peripheral tachykinin receptors as targets for new drugs. Eur J Pharmacol 2001; 429: 13-21.

25. Saffroy M, Torrens Y, Glowinski J, Beaujouan J. Autoradiographic distribution of tachykinin NK2 binding sites in the rat brain: comparison with NK1 and NK3 binding sites. Neuroscience 2003; 116: 761-773.

26. Helke C, Krause J, Mantyh P, Couture R, Bannon M. Diversity in mammalian tachykinin peptidergic neurons: multiple peptides, receptors, and regulatory mechanisms. FASEB J 1990; 4: 1606-1615.

27. Reichard G, Grice C, Shih N, Spitler J, Majmundar S, Paliwal S, Anthes J, Piwinski J. Preparation of oxime dual NK1/NK2 antagonists with reduced NK3 affinity. Bioorg Med Chem Lett 2002; 12: 2355-2358.

28. Noritake KI, Suzuki J, Matsuoka T, Makino T, Ohnishi H, Shimomura K, Uenoyama Y, Tsukamura H, Maeda KI, Sanbuissho A. Testicular toxicity induced by a triple neurokinin receptor antagonist in male dogs. Reprod Toxicol 2010; in press.

29. Harlan R, Garcia M, Krause J. Cellular localization of substance P- and neurokinin Aencoding preprotachykinin mRNA in the female rat brain. J Comp Neurol 1989; 287: 179-212.

30. Marksteiner J, Sperk G, Krause J. Distribution of neurons expressing neurokinin B in the rat brain: immunohistochemistry and in situ hybridization. J Comp Neurol 1992; 317: 341-356.

31. Yamano M, Inagaki S, Kito S, Tohyama M. A substance P-containing pathway from the hypothalamic ventromedial nucleus to the medial preoptic areaof the rat: an immunohistochemical analysis. Neuroscience 1986; 18: 396-402.

32. Valentino K, Tatemoto K, Hunter J, Barchas J. Distribution of neuropeptide K-immunoreactivity in the rat central nervous system. Peptides 1986; 7: 1043-1059.

33. Bittencourt JC, Benoit R, Sawchenko PE. Distribution and origins of substance Pimmunoreactive projections to the paraventricular and supraoptic nuclei: partial overlap with ascending catecholaminergic projections. J Chem Neuroanat 1991; 4: 63-78.

34. Tsuruo Y, Kawano H, Nishiyama T, Hisano S, Daikoku S. Substance P-like immunoreactive neurons in the tuberoinfundibular area of rat hypothalamus. Light and electron microscopy. Brain Res 1983; 289: 1-9.

35. Tsuruo Y, Kawano H, Hisano S, Kagotani Y, Daikoku S, Zhang T, Yanaihara N. Substance P-containing neurons innervating LHRH-containing neurons in the septo-preoptic area of rats. Neuroendocrinology 1991; 53: 236-245.

36. Dudás B, Merchenthaler I. Close juxtapositions between LHRH immunoreactive neurons and substance $\mathrm{P}$ immunoreactive axons in the human diencephalon. J Clin Endocrinol Metab 2002; 87: 2946-2953.

37. Vijayan E, McCann SM. In vivo and in vitro effects of substance $P$ and neurotensin on gonadotropin and prolactin release. Endocrinology 1979; 105: 64-68.

38. Kalra P, Sahu A, Bonavera J, Kalra S. Diverse effects of tachykinins on luteinizing hormone release in male rats: mechanism of action. Endocrinology 1992; 131: 11951201.

39. Picanco-Diniz DL, Valenca MM, Franci CR, Antunes-Rodrigues J. Role of substance $\mathrm{P}$ in the medial preoptic area in the regulation of gonadotropin and prolactin secretion in normal or orchidectomized rats. Neuroendocrinology 1990; 51: 675-682.

40. Sahu A, Kalra S. Effects of tachykinins on luteinizing hormone release in female rats: potent inhibitory action of neuropeptide K. Endocrinology 1992; 130: 1571-1577.

41. Merchenthaler I, Maderdrut J, O'Harte F, Conlon J. Localization of neurokinin B in the central nervous system of the rat. Peptides 1992; 13: 815-829.

42. Goubillon M, Forsdike R, Robinson J, Ciofi P, Caraty A, Herbison A. Identification of neurokinin B-expressing neurons as an highly estrogen-receptive, sexually dimorphic cell group in the ovine arcuate nucleus. Endocrinology 2000; 141: 4218-4225.

43. Foradori C, Amstalden M, Goodman R, Lehman M. Colocalisation of dynorphin a and neurokinin B immunoreactivity in the arcuate nucleus and median eminence of the sheep. J Neuroendocrinol 2006; 18: 534-541.

44. Krajewski S, Anderson M, Iles-Shih L, Chen K, Urbanski H, Rance N. Morphologic evidence that neurokinin $\mathrm{B}$ modulates gonadotropin-releasing hormone secretion via neurokinin 3 receptors in the rat median eminence. J Comp Neurol 2005; 489: 372-386.

45. Sandoval-Guzman T, Rance NE. Central injection of senktide, an NK3 receptor agonist, or neuropeptide $\mathrm{Y}$ inhibits LH secretion and induces different patterns of Fos expression in the rat hypothalamus. Brain Res 2004; 1026: 307-312.

46. Kung T, Crawley Y, Jones H, Luo B, Gilchrest H, Greenfeder S, Anthes J, Lira S, Wiekowski M, Cook D, Hey J, Egan R, Chapman R. Tachykinin NK3-receptor deficiency does not inhibit pulmonary eosinophilia in allergic mice. Pharmacol Res 2004; 50: 611-615.

47. Nishi T, Ishibashi $K$, Takemoto T, Nakajima K, Fukazawa T, Iio $\mathbf{Y}$, Itoh $K_{\text {, }}$ Mukaiyama O, Yamaguchi T. Combined tachykinin receptor antagonist: synthesis and stereochemical structure-activity relationships of novel morpholine analogues. Bioorg Med Chem Lett 2000; 10: 1665-1668.

48. Tsuchida H, Takahashi S, Nosaka E, Mukaiyama O, Yamashita M, Morimoto K. Novel triple neurokinin receptor antagonist CS-003 strongly inhibits neurokinin related responses. Eur J Pharmacol 2008; 586: 306-312.

49. Fujii T, Murai M, Morimoto H, Maeda Y, Yamaoka M, Hagiwara D, Miyake H, Ikari N, Matsuo M. Pharmacological profile of a high affinity dipeptide NK1 receptor antagonist, FK888. Br J Pharmacol 1992; 107: 785-789.

50. Emonds-Alt $X$, Vilain $P$, Goulaouic $P$, Proietto V, Van Broeck D, Advenier C, Naline E, Neliat G, Le Fur G, Brelière J. A potent and selective non-peptide antagonist of the neurokinin A (NK2) receptor. Life Sci 1992; 50: PL101-106.

51. Sarau H, Griswold D, Potts W, Foley J, Schmidt D, Webb E, Martin L, Brawner M, Elshourbagy N, Medhurst A, Giardina G, Hay D. Nonpeptide tachykinin receptor antagonists: I. Pharmacological and pharmacokinetic characterization of SB 223412, a novel, potent and selective neurokinin-3 receptor antagonist. J Pharmacol Exp Ther 1997; 281: 1303-1311.

52. Paxinos G, Watson C. The Rat Brain in Stereotaxic Coordinates. 6th ed., San Diego: Academic Press; 1997.

53. Merriam GR, Wachter KW. Algorithms for the study of episodic hormone secretion. Am J Physiol 1982; 243: E310-318.

54. Maeda KI, Tsukamura H, Uchida E, Ohkura N, Ohkura S, Yokoyama A. Changes in the pulsatile secretion of $\mathrm{LH}$ after the removal of and subsequent resuckling by pups in ovariectomized lactating rats. J Endocrinol 1989; 121: 277-283.

55. Tsuchida H, Takahashi S, Nosaka E, Kuraya T, Yamashita M, Morimoto K. Nove triple neurokinin receptor antagonist CS-003 inhibits respiratory disease models in guinea pigs. Eur J Pharmacol 2008; 596: 153-159.

56. Ohkura S, Takase K, Matsuyama S, Mogi K, Ichimaru T, Wakabayashi $Y$ Uenoyama Y, Mori Y, Steiner RA, Tsukamura H, Maeda KI, Okamura H. Gonadotrophin-releasing hormone pulse generator activity in the hypothalamus of the goat. J Neuroendocrinol 2009; 21: 813-821.

57. Corander MP, Challis BG, Thompson EL, Jovanovic Z, Loraine Tung YC, Rimming ton D, Huhtaniemi IT, Murphy KG, Topaloglu AK, Yeo GS, O'Rahilly S, Dhillo WS, Semple RK, Coll AP. The effects of neurokinin B upon gonadotrophin release in male rodents. J Neuroendocrinol 2010; 22: 181-187.

58. Larsen P, Saermark T, Mau S. Binding of an iodinated substance P analogue to cultured anterior pituitary prolactin- and luteinizing hormone-containing cells. J Histochem Cytochem 1992; 40: 487-493.

59. Shamgochian $\mathbf{M}$, Leeman $\mathbf{S}$. Substance $\mathbf{P}$ stimulates luteinizing hormone secretion from anterior pituitary cells in culture. Endocrinology 1992; 131: 871-875. 